\title{
Carbon Stock of Prevailing Land Use Systems under East Siang District, Arunachal Pradesh, India
}

\author{
Royal L. Mihriemate ${ }^{1}$, Bikram Singh ${ }^{1 *}$ and A.S. Mailappa ${ }^{2}$ \\ ${ }^{1}$ Department of Silviculture and Agroforestry, ${ }^{2}$ College of Horticulture and Forestry, Central \\ Agricultural University, Pasighat-791102, Arunachal Pradesh, India \\ *Corresponding author
}

\section{Keywords}

Land use, Carbon stock, Carbon sequestration,

Biomass and organic carbon

Article Info

Accepted:

20 May 2020 Available Online: 10 June 2020

\section{A B S T R A C T}

The present investigation were carried out in split plot design using six land use system, natural grassland $\left(T_{1}\right)$, natural forest $\left(T_{2}\right)$, agriculture field $\left(T_{3}\right)$, rubber plantation $\left(\mathrm{T}_{4}\right)$, teak plantation $\left(\mathrm{T}_{5}\right)$ and tea plantation $\left(\mathrm{T}_{6}\right)$ at three soil layers and replicated thrice under Pasighat Forest Division of East Siang District, (Arunachal Pradesh). The results have revealed higher total biomass production level $\left(770.78 \mathrm{t} \mathrm{ha}^{-1}\right)$ by teak plantation followed by natural forest (424.54 $\left.\mathrm{t} \mathrm{ha}^{-1}\right)$, which affect the carbon stock and carbon sequestration potential. While minimum of total biomass production was found in natural grassland. Soil organic carbon and soil organic stock was higher in natural forest and teak plantation, enhances belowground carbon storage. As a result, the maximum total carbon stock was recorded in teak plantation (405.13 $\mathrm{t} \mathrm{ha}^{-1}$ ) followed by natural forest, rubber plantation, tea plantation and agriculture field while minimum total carbon stock was recorded in natural grassland $\left(8.44 \mathrm{t} \mathrm{ha}^{-1}\right)$. The study highlights the opportunity to increase carbon storage potential through trees.

\section{Introduction}

Carbon sequestration through sink enhancement by way of integration of trees into landscapes is one of the cost-effective mitigation strategies in the terrestrial ecosystem may be categorized into vegetative carbon and soil carbon components. The capacity of terrestrial ecosystems to sequester carbon varies based on its land use patterns. Land use, land use change and forestry (LULUCF), an approach that became popular in the context of the Kyoto protocol, allows afforestation and reforestation as greenhouse gas offset activities (Nair et al., 2011).

Decisions about terrestrial carbon sequestration need a deliberate exploration for 
adjustments among multiple resources for ecosystem benefits. Agricultural lands are believed to be a major potential sink and could observe large quantities of carbon if trees are introduced to these systems and judiciously manage together with crops, trees accumulating carbon in wood as they grow and acting as stable carbon stores upon maturity. By promoting different tree based land use system with higher carbon contents, a net gain in the existing carbon stock can be realized. The most significant increase in carbon storage can be achieved by moving from lower biomass to higher biomass land use system such as teak plantation, rubber plantation, etc. Teak plantation provide as high as $635.33 \mathrm{t} \mathrm{ha}^{-1}$ of above ground biomass in hilly zone as reported by Reddy, et al., (2014).

Soils are also an effective sink for carbon. However, soil carbon stocks vary as a function of different land management practices, landscape position and vegetation productivity. Findings estimate that the global potential of soil carbon sequestration is 0.4 to $1.2 \mathrm{Gt} \mathrm{C} \mathrm{yr}^{-1}$, or an amount equal to roughly 5 to $15 \%$ of total man-made $\mathrm{CO}_{2}$ emissions. The soil organic carbon concentration is considered to be the highest in forestry, followed by horticulture; while the least efficient is agriculture (Sharma et al., 2014). To be most effective, $\mathrm{CO}_{2}$ must be fixed into long-lived pools (or "sinks") by transfer of atmospheric $\mathrm{CO}_{2}$ into the soil, plays an important role in the global $\mathrm{C}$ cycle (GCC).

In Arunachal Pradesh, land use pattern under tropical ecosystem lying between $100 \mathrm{~m}$ to $200 \mathrm{~m}$ above sea level has under gone a significant change upon the introduction of tea, rubber, etc. as cash crops. Although these changes in the land use will greatly revolutionize the economy of the people but no study has been carried out to know the carbon stock and sequestration potential of these changed land uses. A realistic estimate of carbon stock at any given time is crucial for indicating the potential of vegetation to released or absorbed carbon and can be used to constrain other methods such as inversed modelling in estimating net carbon flux (Goodale et al., 2002). Therefore, an attempt with the present investigation was undertaken to determine the carbon stock of prevailing land use systems under East Siang District, Arunachal Pradesh.

\section{Materials and Methods}

The study was conducted in Pasighat Forest Division of East Siang District, Arunachal Pradesh, India $\left(94^{\circ} 42^{\prime}\right.$ to $95^{\circ} 35^{\prime} \mathrm{E}$ and $27^{\circ}$ $43^{\prime}$ to $29^{\circ} 20^{\prime} \mathrm{N}$ ) with an elevation of $155 \mathrm{~m}$ (a.s.l). The climate characteristics of this area is generally humid sub-tropical, receives more than $4000 \mathrm{~mm}$ average rainfall. The annual mean maximum temperature is $31 \pm 1.1^{\circ} \mathrm{C}$ and the mean minimum temperature is $18 \pm 1.2^{\circ} \mathrm{C}$ with soil type of entisols, inceptisols. The research method laid out in split plot design focused on six land use system (T), three soil layers (L) and replicated thrice. The six land use system were: natural grassland $\left(\mathrm{T}_{1}\right)$, natural forest $\left(\mathrm{T}_{2}\right)$, agriculture field $\left(\mathrm{T}_{3}\right)$, rubber plantation $\left(\mathrm{T}_{4}\right)$, teak plantation $\left(\mathrm{T}_{5}\right)$ and tea plantation $\left(\mathrm{T}_{6}\right)$. The soil sample collected from sampling sites using random sampling technique from three depth of soil layers extracted at: $0-15 \mathrm{~cm}\left(\mathrm{~L}_{1}\right), 15-30 \mathrm{~cm}$ $\left(\mathrm{L}_{2}\right)$, and $30-45 \mathrm{~cm}\left(\mathrm{~L}_{3}\right)$. The plot size of each land use system was $50 \mathrm{~m} \times 10 \mathrm{~m}$ except for natural grassland and agriculture field where the plot size was $1 \mathrm{~m} \times 1 \mathrm{~m}$ quadrates. The observations of the tree species were recorded during September-October, 2017. The tree height and form height were measured using Spiegel Relaskop. The girth at breast height (GBH) measured with the help of measuring tape was converted to diameter at breast height by $\mathrm{DBH}$; form factor and volume were calculated using the formula given by 
Bitterlich (1984) and Pressler (1865) respectively. The above-ground biomass $\left(\mathrm{t} \mathrm{ha} \mathrm{H}^{-1}\right)$ has been calculated by multiplying volume with specific gravity. Estimation of wood specific gravity followed by Gupta $e t$ al., (2017) and Williamson and Wiemann (2010). The sample branches and leaves of tree were taken for total dry biomass estimation. The biomass value for the three tree component (stem, branch and leaf) were obtained by summing up all the three values.

The root system weight about 20 per cent, as much as the above ground weight of the tree. Therefore, $20 \%$ of the total above ground biomass were considered as root biomass (below-ground biomass) as given by Achard et al., (2002) and Ramankutty et al., (2007). The crop and grass biomass were estimated by collection of samples (harvested at ground level) of the quadrate and oven-dried to estimate the weight. Biomass estimated for different strata were summed to calculate total above-ground biomass and carbon stock by multiplying estimated dry biomass weight with 0.47 as suggested by IPCC (2000) and IPCC methodologies default 0.47 carbon percent (Mc Groddy et al., 2004). The bulk density was calculated as method described by Singh et al., (1986). Organic carbon was determined by Walkley and Black (1934) and the soil organic carbon was computed by using the formulae of Nelson and Sommers (1996).

Soil Carbon stock $\left(\mathrm{t} \mathrm{ha}^{-1}\right)=[$ soil bulk density $\left.\left(\mathrm{g} \mathrm{cm}^{-3}\right)\right] \mathrm{x}$ soil depth $(\mathrm{cm}) \mathrm{x}$ soil carbon $(\%)$

Total carbon stock $=$ plant carbon stock + soil carbon stock

The data obtained were subjected to statistical analysis using split plot of experimentation as per the procedure suggest by Gomez and Gomez (1984).

\section{Results and Discussion}

Biomass production: The biomass production level and carbon stock depends upon the land use systems, structure, and intensity of management. The maximum above ground $\left(642.32 \mathrm{t} \mathrm{ha}^{-1}\right)$ biomass production level was demonstrated by teak plantation (table 1) followed by natural forest (353. $79 \mathrm{t} \mathrm{ha}^{-1}$ ), rubber plantation $\left(130.59 \mathrm{t} \mathrm{ha} \mathrm{ha}^{-1}\right)$, tea plantation $\left(41.37 \mathrm{t} \mathrm{ha}^{-1}\right)$ and agriculture field $\left(7.83 \mathrm{t} \mathrm{ha}^{-1}\right)$, and minimum above ground biomass production was found in natural grassland $\left(2.98 \mathrm{t} \mathrm{ha}^{-1}\right)$. Similar significant trend was observed in below ground biomass production and total biomass production.

Biomass carbon stock: Above ground biomass carbon stock (301.89 $\left.\mathrm{t} \mathrm{ha}^{-1}\right)$ was higher in teak plantation followed by natural forest $\left(166.28 \mathrm{t} \mathrm{ha}^{-1}\right)$, rubber plantation $(61.38$ $\left.\mathrm{t} \mathrm{ha}^{-1}\right)$, tea plantation $\left(19.45 \mathrm{t} \mathrm{ha}^{-1}\right)$ and agriculture field $\left(3.68 \mathrm{tha}^{-1}\right)$ and was found lower $\left(1.40 \mathrm{t} \mathrm{ha}^{-1}\right)$ in natural grassland. Similar trend was observed in below ground biomass carbon stock and total biomass carbon stock (table 1).

Bulk density: A gradual increase in bulk density with increase in depth of soil for all the land use systems was observed in all the land use systems under the investigation. A significant difference in bulk density was seen at three depths (Table 2). Highest bulk density was recorded in natural grassland (1.36 $\left.\mathrm{g} \mathrm{cm}^{-3}\right)$ and agriculture field $\left(0.96 \mathrm{~g} \mathrm{~cm}^{-3}\right)$ was recorded the lowest.

Soil organic carbon and soil carbon stock: The results revealed highest soil organic carbon in natural forest $(1.42 \%)$ and natural grassland $(0.20 \%)$ was exhibited lowest (Table 2). Similarly soil carbon stock had highest in natural forest $\left(49.21 \mathrm{t} \mathrm{ha}^{-1}\right)$ followed by teak plantation $\left(42.86 \mathrm{t} \mathrm{ha}^{-1}\right)$ and natural grassland $\left(6.76 \mathrm{t} \mathrm{ha}^{-1}\right)$ was recorded 
lowest. While in order of soil layers, the soil organic carbon decreased with increase in depth, while soil carbon stock increases with increase in depth of soil in general in all the land use systems.

Total carbon stock: The estimation of the total carbon stock in six land use system are shown in Figure. 1. The significantly higher total carbon stock was recorded in teak plantation $\left(405.13 \mathrm{t} \mathrm{ha}^{-1}\right)$ followed by natural forest $\left(248.75 \mathrm{t} \mathrm{ha}^{-1}\right)$, rubber plantation $\left(106.75 \mathrm{t} \mathrm{ha}^{-1}\right)$, tea plantation $\left(55.25 \mathrm{t} \mathrm{ha}^{-1}\right)$ and agriculture field $\left(22.90 \mathrm{t} \mathrm{ha}^{-1}\right)$, while natural grassland $\left(8.44 \mathrm{t} \mathrm{ha}^{-1}\right)$ was recorded lowest.

Table.1 Biomass production levels and biomass carbon stock of above ground biomass (ABG), below ground biomass (BG) and total biomass (T. Bio) in different land use systems

\begin{tabular}{|c|c|c|c|}
\hline Land use systems & Characters & $\begin{array}{c}\text { Biomass production } \\
\text { levels }\left(\mathrm{t} \mathrm{ha}^{-1}\right)\end{array}$ & $\begin{array}{l}\text { Biomass carbon } \\
\text { stock }\left(\mathrm{t} \mathrm{ha}^{-1}\right)\end{array}$ \\
\hline \multirow{3}{*}{$T_{1}=$ Natural grassland } & $\mathrm{ABG}$ & 2.98 & 1.4 \\
\hline & BG & 0.6 & 0.28 \\
\hline & T. Bio & 3.58 & 1.68 \\
\hline \multirow{3}{*}{$T_{2}=$ Natural forest } & ABG & 353.79 & 166.28 \\
\hline & BG & 70.76 & 33.26 \\
\hline & T. Bio & 424.54 & 199.54 \\
\hline \multirow{3}{*}{$T_{3}=$ Agriculture field } & ABG & 7.83 & 3.68 \\
\hline & BG & 1.57 & 0.74 \\
\hline & T. Bio & 9.4 & 4.42 \\
\hline \multirow[t]{3}{*}{$T_{4}=$ Rubber plantation } & $\mathrm{ABG}$ & 130.59 & 61.38 \\
\hline & BG & 26.12 & 12.28 \\
\hline & T. Bio & 156.71 & 73.65 \\
\hline \multirow[t]{3}{*}{$\mathbf{T}_{5}=$ Teak plantation } & ABG & 642.32 & 301.89 \\
\hline & BG & 128.46 & 60.38 \\
\hline & T. Bio & 770.78 & 362.27 \\
\hline \multirow{3}{*}{$T_{6}=$ Tea plantation } & $\mathrm{ABG}$ & 41.37 & 19.45 \\
\hline & BG & 8.27 & 3.89 \\
\hline & T. Bio & 49.65 & 23.33 \\
\hline \multicolumn{2}{|l|}{ Factors } & $\mathrm{CD}_{0.05}$ & $\mathrm{CD}_{0.05}$ \\
\hline \multicolumn{2}{|l|}{ Factor(T) } & $11.46^{*}$ & $5.38^{*}$ \\
\hline \multicolumn{2}{|l|}{ Factor(C) } & $2.82^{*}$ & $1.33^{*}$ \\
\hline \multicolumn{2}{|c|}{ Factor(C)at same level of $\mathbf{T}$} & $7.38^{*}$ & $3.47^{*}$ \\
\hline \multicolumn{2}{|c|}{ Factor(T)at same level of $\mathrm{C}$} & $12.77 *$ & $6.00^{*}$ \\
\hline
\end{tabular}

* Significant at the $0.05 p$ level. 
Table.2 Bulk density, soil organic carbon and soil carbon stock

\begin{tabular}{|c|c|c|c|c|c|c|c|}
\hline \multirow[t]{2}{*}{$\begin{array}{l}\text { Landuse } \\
\text { systems }\end{array}$} & \multirow{2}{*}{$\begin{array}{l}\text { Soil } \\
\text { layers } \\
\text { (cm) }\end{array}$} & \multicolumn{2}{|c|}{$\begin{array}{l}\text { Bulk density } \\
\quad\left(\mathrm{g} \mathrm{cm}^{-3}\right)\end{array}$} & \multicolumn{2}{|c|}{$\begin{array}{c}\text { Soil organic carbon } \\
(\%)\end{array}$} & \multicolumn{2}{|c|}{$\begin{array}{l}\text { Soil carbon stock } \\
\left(\mathrm{t} \mathrm{ha}^{-1}\right)\end{array}$} \\
\hline & & Actual & mean & Actual & mean & Actual & mean \\
\hline \multirow{3}{*}{$\begin{array}{l}\mathrm{T}_{1}=\text { Natural } \\
\text { grassland }\end{array}$} & $\mathrm{L}_{1}(0-15)$ & 1.16 & \multirow[t]{3}{*}{1.36} & 0.3 & \multirow[t]{3}{*}{0.2} & 5.3 & \multirow[t]{3}{*}{6.76} \\
\hline & $\mathrm{L}_{2}(15-30)$ & 1.37 & & 0.22 & & 8.91 & \\
\hline & $\mathrm{L}_{3}(30-45)$ & 1.56 & & 0.09 & & 6.07 & \\
\hline \multirow{3}{*}{$\begin{array}{l}T_{2}=\text { Natural } \\
\text { forest }\end{array}$} & $\mathrm{L}_{1}(0-15)$ & 1.15 & \multirow[t]{3}{*}{1.18} & 1.54 & \multirow[t]{3}{*}{1.42} & 26.43 & \multirow[t]{3}{*}{49.21} \\
\hline & $\mathrm{L}_{2}(15-30)$ & 1.18 & & 1.44 & & 51.13 & \\
\hline & $\mathrm{L}_{3}(30-45)$ & 1.22 & & 1.28 & & 70.09 & \\
\hline \multirow{3}{*}{$\begin{array}{l}T_{3}=\text { Agriculture } \\
\text { field }\end{array}$} & $\mathrm{L}_{1}(0-15)$ & 0.89 & \multirow[t]{3}{*}{0.96} & 1.1 & \multirow[t]{3}{*}{0.86} & 14.74 & \multirow[t]{3}{*}{22.9} \\
\hline & $\mathrm{L}_{2}(15-30)$ & 0.96 & & 0.83 & & 24.08 & \\
\hline & $\mathrm{L}_{3}(30-45)$ & 1.02 & & 0.65 & & 29.89 & \\
\hline \multirow{3}{*}{$\begin{array}{l}\mathrm{T}_{4}=\text { Rubber } \\
\text { plantation }\end{array}$} & $\mathrm{L}_{1}(0-15)$ & 1.02 & \multirow[t]{3}{*}{1.06} & 1.32 & \multirow[t]{3}{*}{1.12} & 20.31 & \multirow[t]{3}{*}{33.1} \\
\hline & $\mathrm{L}_{2}(15-30)$ & 1.06 & & 1.21 & & 38.35 & \\
\hline & $\mathrm{L}_{3}(30-45)$ & 1.1 & & 0.82 & & 40.64 & \\
\hline \multirow{3}{*}{$\begin{array}{l}T_{5}=\text { Teak } \\
\text { plantation }\end{array}$} & $\mathrm{L}_{1}(0-15)$ & 1.07 & \multirow[t]{3}{*}{1.11} & 1.51 & \multirow[t]{3}{*}{1.34} & 24.21 & \multirow[t]{3}{*}{42.86} \\
\hline & $\mathrm{L}_{2}(15-30)$ & 1.1 & & 1.33 & & 43.64 & \\
\hline & $\mathrm{L}_{3}(30-45)$ & 1.15 & & 1.17 & & 60.73 & \\
\hline \multirow{3}{*}{$\begin{array}{l}T_{6}=\text { Tea } \\
\text { plantation }\end{array}$} & $\mathrm{L}_{1}(0-15)$ & 1.12 & \multirow[t]{3}{*}{1.15} & 1.11 & \multirow[t]{3}{*}{0.96} & 18.7 & \multirow[t]{3}{*}{31.91} \\
\hline & $\mathrm{L}_{2}(15-30)$ & 1.15 & & 0.95 & & 32.66 & \\
\hline & $\mathrm{L}_{3}(30-45)$ & 1.18 & & 0.83 & & 44.39 & \\
\hline \multicolumn{2}{|l|}{ Factors } & \multicolumn{2}{|l|}{$\mathrm{CD}_{0.05}$} & \multicolumn{2}{|l|}{$\mathrm{CD}_{0.05}$} & \multicolumn{2}{|l|}{$\mathrm{CD}_{0.05}$} \\
\hline Factor(T) & & $0.022 *$ & & $0.03 *$ & & $1.04 *$ & \\
\hline Factor(C) & & $0.015 *$ & & $0.03 *$ & & $0.91 *$ & \\
\hline Factor(C)at sam & level of $T$ & $0.037 *$ & & $0.06^{*}$ & & $2.29 *$ & \\
\hline Factor(T)at same & level of C & $0.037 *$ & & $0.06^{*}$ & & $2.11 *$ & \\
\hline
\end{tabular}

* Significant at the $0.05 p$ level.

Fig.1 Total carbon stock $\left(\mathrm{t} \mathrm{ha}^{-1}\right)$ in different land use system

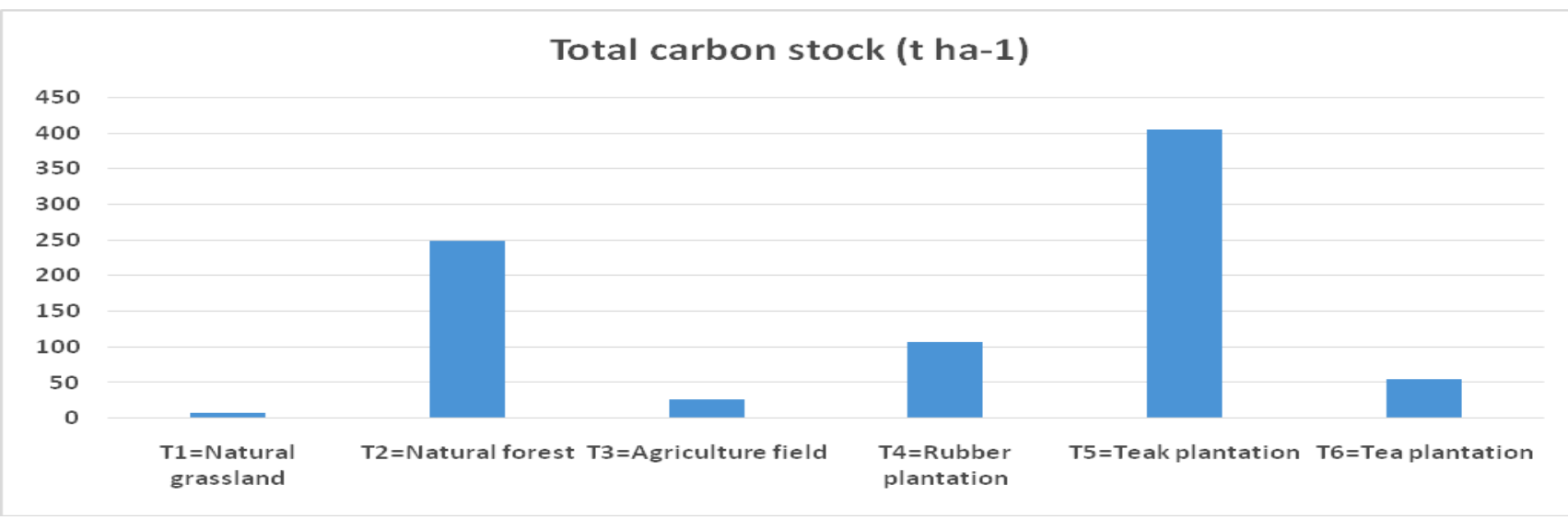


It is evident from the present study that there is highly significant influence of prevailing land use change and management effects on biomass production levels and are relatively well known. The total biomass production level (770.78 $\mathrm{t} \mathrm{ha}^{-1}$ ) was demonstrated by teak plantation followed by natural forest $(424.54 \mathrm{t}$ $\mathrm{ha}^{-1}$ ) while highest soil organic carbon in natural forest $(1.42 \%)$ and teak plantation $(1.34 \%)$ reveals that trees and wooded areas may store carbon by sequestering atmospheric carbon which are potential natural carbon sink and increase soil organic carbon (Brown and Pearcel, 1994). The results are in line with the findings of Singh et al., (2009) and Haripriya (2000). Chhetri (2007) reported that soil with high organic carbon content is of high quality and higher soil carbon stock is a pathway of input of new soil organic carbon into the soil. As the tree roots enhances belowground carbon storage (Howlett et al., 2011), the present investigation undertaken for soil carbon stock in natural forest (49.21 $\left.\mathrm{t} \mathrm{ha}^{-1}\right)$ and teak plantation (42.86 $\left.\mathrm{t} \mathrm{ha} \mathrm{ha}^{-1}\right)$ were relatively higher as compared to natural grassland $\left(6.76 \mathrm{t} \mathrm{ha}^{-1}\right)$ which contributed low soil organic carbon stock due to the removal of grass due to grazing and fodder collection. Similar findings were reported by Dhruw et al., (2009); Negi et al., (2003) and Chimdi et al., (2012). However, carbon stock has tremendous impacts on improving soil productivity and reducing green house gases emission, total carbon stock was recorded higher in teak plantation $\left(\mathrm{T}_{5}\right)$ followed by natural forest $\left(\mathrm{T}_{2}\right)$ as compared to the rest of four land use system studied, the findings indicate an opportunity to increase carbon storage via trees, that accumulate more carbon content in stem and roots. Similar results were reported by Reddy et al., (2014) and Arya et al., (2018).

In conclusion, teak plantation and natural forest which represents maximum biomass carbon production and carbon stock among the six prevailing land use system. In conclusion, the results of this study inferred that teak plantation has the potential to sequester carbon from the atmosphere, and further the natural forest should not be disturbed, and other tree based land use system should be encouraged, where ever any opportunity in areas of agriculture field, Tree outside Forests (ToF) or agroforestry based land use system should be followed to increase the carbon sequestration potential of the region.

\section{Acknowledgements}

This research formed part of the M.Sc. (Forestry) thesis submitted to the Central Agricultural University, Imphal, Manipur, India by the first author. Facilities for testing the samples provided by the Dean, College of Horticulture \& Forestry, CAU, Pasighat, Arunachal Pradesh for providing all kinds of help and the technical guidance rendered by faculty of different department of $\mathrm{CHF}$, Pasighat during investigation are gratefully acknowledged.

\section{References}

Achard, F., Eva, H.D., Stibig, H.J., Mayaux, P., Gallego, J., Richards, T. and Malingrean, J.P. 2002. Determination of deforestation rates of the world's human tropical forest. Science, 297(5583): 9991002.

Arya, R., Mishra, A.K. and Chaudhry, S. 2018. Variation in Soil Properties and Carbon Stocks under Roadside Plantation and Rice-Wheat Cropping System in North Western Haryana, India. Int. J. Curr. Microbiol. App. Sci., 7(4): 1939-1949

Bitterlich, W. 1984. The Relascope Idea: Relative Measurements in Forestry. Commonwealth Agricultural Bureaux, England. pp. 242. 
Brown, K. and Pearce, D.W. 1994. The economic value of non-marketed benefits of tropical forests: carbon storage. In: Weiss, J. (Ed.), The Economics of Project Appraisal and the Environment, Aldershot, UK and Brookfield, US: Edward Elgar, London, pp. 102-123.

Chhetri, P. K. 2007. Assessment of soil quality index and soil organic carbon stock under different land use, elevation and aspect in Upper Harpan Subwatershed, Kaski, B.Sc thesis. [ONLINE] Available at:http://www.forestrynepal.org/publicat ions/thesis/4132 [Accessed 23 June 2014].

Chimdi, A., Gebrekidan, H., Kibret, K., and Tadesse, A. 2012. Status of selected physicochemical properties of soils under different land use systems of Western Oromia, Ethiopia. J. Bio. Env. Sci., 2: 57-71.

Dhruw, S.K., L. Singh and Singh, A.K. 2009. Storage and sequestration of carbon by leguminous and non-leguminous trees on red-lateritic soil of Chhattisgarh. Indian Forester, 135(4): 531-538.

Gomez, K.A. and Gomez, A.A. 1984. Statistical procedures for agricultural research. $2^{\text {nd }}$ edn. John Wiley and Sons, New York. pp. 680.

Goodale, C.L., Apps, M.J., Birdsey, R.A., Field, C.B., Heath, L.S., Houghton, R.A., Jenkins, J.C., Kohlmaier, G.H., Kurz, W., Liu, S., Nabuurs, G.J., Nilsson, S. and Shvidenko, A.Z. 2002. Forest carbon sinks in the Northern Hemisphere. Ecol. Appl., 12(3): 891899.

Gupta, D.K., Bhatt, R. K., Keerthika, A., Shukla, A. K., Noor Mohamed, M.B. and Jangid, B. L. 2017. Wood specific gravity of trees in hot semi-arid zone of India: diversity among species and relationship between stem and branches.
Current Science, 113(8): 1597-1600.

Haripriya, G.S. 2000. Estimates of biomass in Indian forests. Biomass Bioenerg., 19: 245-258.

Howlett, D.S., Mosquera-Losada, M.R., Nair, P.K.R., Nair, V.D., and Rigueiro Rodríguez, A. 2011. Soil C storage in silvopastoral systems and a tree less pasture in north-western Spain. Journal of Environmental Quality, 40: 1-8.

IPCC. 2000. Land use, Land use change and Forestry: A special report. Cambridge University Press, Cambridge, U.K.

Mc Groddy, M.E., Daufresne, T. and Hedin, L.O. 2004. Scaling of C:N:P stoichiometry in forests worldwide: implications of terrestrial Red-field type ratios. Ecology, 85(9): 2390-2401.

Nair, P.K.R., Vimala, D.N., Kumar, B.M. and Showalter, J.M. 2011. Carbon sequestration in agroforestry systems. Adv. Agron., 108: 237-307.

Negi, J.D.S., R.K. Manhas and Chauhan, P.S. 2003. Carbon allocation in different components of some tree species of India: a new approach for carbon estimation. Current Science, 85(11): 1528-1531.

Nelson, D.W. and Sommers, L.E. 1996. Total carbon, organic carbon, and organic matter. In: Spark, D.L., Page, A.L., Helmke, P.A., Loeppert, R.H., Soltanpour, P.N., Tabatabai, M.A., Johnston, C.T. and Sumner, M.E. (Ed.), Methods of soil analysis. Part 3, chemical methods. Madison, USA, Soil science society of America and American society of agronomy. pp. 961-1010.

Pressler, M. 1865. Das Gesetz der Stammformbildung. Verlag Arnold, Leipzig. pp. 153.

Ramankutty, N., Gibbs, H.K., Achard, F., DeFries, R., Foley, J.A. and Houghton, R.A. 2007. Challenges to estimating carbon emission from tropical 
deforestation. Glob. Chang. Biol., 13: 51-66.

Reddy, M.C., Priya, R.M. and Madiwalar, S.L. 2014. Carbon sequestration potential of teak plantations of different agro-climatic zones and age-gradations of Southern India. Curr. World Environ., 9(3): 785-788.

Sharma, V., Hussain, S., Sharma, K.R. and Arya, V.M. 2014. Labile carbon pools and soil organic carbon stocks in the foothill Himalayas under different land use systems. Geoderma, 232-234, 8187.

Singh, A.K., Parsad, A. and Singh, B. 1986. Availability of phosphorus and potassium and its relationship with physico-chemical properties of some forest soils of pali-range Shahodol, M.P Indian Forester, 112(12):1094-1104.

Singh, P. and Lodhiyal, L.S. 2009. Biomass and carbon allocation in 8-year-old poplar (Populus deltoides Marsh.) plantation in terai agroforestry systems of Central Himalaya, India. N.Y. Sci. J., 2(6): 49-53.

Walkley, A.J. and Black, I.A. 1934. Estimation of soil organic carbon by chronic acid titration method. Soil Sci., 37: 29-38.

Williamson, G.B., and Wiemann, M.C. 2010. Measuring wood specific gravity....correctly. American Journal of Botany, 97:519-524.

\section{How to cite this article:}

Royal L. Mihriemate, Bikram Singh and Mailappa, A.S. 2020. Carbon Stock of Prevailing Land Use Systems under East Siang District, Arunachal Pradesh, India. Int.J.Curr.Microbiol.App.Sci. 9(06): 2568-2575. doi: https://doi.org/10.20546/ijcmas.2020.906.312 